\title{
Ortaöğretim Öğretmenlerinin Öğrenmeye ve Öğretmenlik Mesleğine İlişkin Tutumlarının İncelenmesi ${ }^{*}$
}

\author{
Ferat DALAMAN \\ Öğretmen, Doğanşehir Fen Lisesi, Malatya, \\ dalamanferat@gmail.com \\ Orcid ID: https://orcid/0000-0001-8443-9683
}

\author{
Ahmet KARA \\ Prof. Dr., İnönü Üniversitesi, Eğitim Fakültesi, \\ Eğitim Programları ve Öğretim Anabilim Dalı, ahmet.kara@inonu.edu.tr \\ Orcid ID: https://orcid/0000-0002-6196-2292
}

\section{Öz}

$\mathrm{Bu}$ araştırmanın amac1; ortaöğretim öğretmenlerinin öğrenmeye ve öğretmenlik mesleğine ilişkin tutumlarını incelemektir. Araştırmanın örneklemini, 2019-2020 Eğitim-Öğretim yılının birinci yarıyılında Malatya ili merkez ilçelerindeki liselerde görev yapan 588 öğretmen oluşturmaktadır. Araştırmada Kara (2010) tarafindan geliştirilen "Öğrenmeye İlişkin Tutum Ölçeği” ve Demirel ile Ünişen (2018) tarafindan geliştirilmiş olan "Öğretmenlerin Öğretmenlik Mesleğine İlişkin Tutum Ölçeği” kullanılmıştır. Araştırma, betimsel yöntem izlenerek gerçekleştirilmiştir. Öğretmenlerin kıdemleri, eğitim düzeyleri ve iş doyum düzeyleri açısından öğrenmenin doğasına ilişkin tutumlarında, öğrenmeye ilişkin kaygılarında, öğrenmeden beklentilerinde, öğrenmeye açı olma tutumlarında, öğretmenlik mesleğine değer verme, mesleki gelişime açıklık, mesleki tükenmişlikleri ve mesleğe ilgisizliklerinde anlamlı farklar gözlenmiştir. Özellikle öğrenmenin doğası, öğrenmeye ilişkin beklentiler, öğrenmeye açık olma ve öğretmenlik mesleğine değer verme tutumlarının artması; Öğrenmeye açık olma, mesleğe değer verme, mesleki tükenmişlik ve mesleğe ilgisizliği artırırken öğrenmeye ilişkin kaygılar ve mesleki gelişime açık olma tutumlarını azalttığı görülmüştür.

Anahtar Kelimeler: Öğretmenlik Mesleği, Öğrenme, Tutum, Öğrenme ve Öğretmenlik Mesleğine İlişkin Tutum, Öğretmen.

\footnotetext{
${ }^{1}$ Makale Geliş/Kabul Tarihi: 17.05.2021/21.12.2021

* Bu makale ikinci yazar danışmanlığında birinci yazarın yüksek lisans tezinden üretilmiştir.

Künye Bilgisi: Dalaman, F. ve Kara, A. (2021). Ortaöğretim öğretmenlerinin öğrenmeye ve öğretmenlik mesleğine iliş̧kin tutumlarının incelenmesi. Kahramanmaraş Sütçü İmam Üniversitesi Sosyal Bilimler Dergisi, 18 (3), 1572-1601. DOI: 10.33437/ksusbd.938265
} 


\title{
The Analyzing of Secondary School Teachers' Attitudes towards Learning and Teaching Profession
}

\begin{abstract}
The aim of this research is to examine secondary school teachers' attitudes towards learning and teaching profession. The sample of the study consists of 588 teachers working at high schools in the central districts of Malatya in the first semester of the 2019-2020 academic year. In the study, "The Scale of Attitudes towards Learning" developed by Kara (2010) and "The Scale of Attitudes towards Teaching Profession" developed by Demirel and Ünişen (2018) were used. After applying the scales to the relevant sampling, the data obtained were transferred to the computer and the computer package program was used to answer the subproblems. This research was carried out in the descriptive method. Significant differences were observed in their attitudes towards the nature of learning, their anxieties about learning, their expectations from learning, their openness to learning, appreciating teaching profession, openness to professional development, occupational burnout and indifference to the profession in terms of the professional seniority of the teachers, their education level and job satisfaction. In particular, it was discovered that while the increases in 'the nature of learning, expectations for learning, openness to learning and appreciating the teaching profession attitudes enhanced 'being open to learning, appreciating the profession, occupational burnout and indifference to the profession', they decreased 'anxiety about learning and attitudes towards being open to professional development.' Depending on the results of this research, it was reasoned that teachers' positive attitudes towards learning and teaching profession should be increased and their negative attitudes should be reduced.
\end{abstract}

Keywords: Teaching Profession, Learning, Attitude, Attitude towards Learning and Teaching Profession, Teacher.

\section{GİRIŞ}

Eğitim sistemini oluşturan birçok unsurun olduğu bilinmekle birlikte, eğitimin niteliğinin ne olduğunu belirleyen en önemli unsurun öğretmenler olduğu şüphe götürmez bir gerçekliktir. Eğitim sisteminde başrol oynayan öğretmenin önem derecesi, eğitim sürecinin diğer unsurları olan öğrenci, eğitim programları vb. unsurlardan daha da yüksektir (Karagözoğlu, 1987). Öğretmen ihtiyacının karşılanması amacıyla 16 Mart 1848 tarihinde Osmanlı Döneminde ilk defa Öğretmen Okulu olan Darül Muallimin-i Rüşti açılmıştır. Bu okulun açılması ile başlayan öğretmen yetiştirme uygulamaları da sürekli değişiklikler göstererek günümüze kadar gelmiştir. Fakat buna rağmen öğretmen yetiştirme uygulamaları 
hakkında üzerinde tam olarak görüş birliğine varılabilen bir sistemin oluşturulamadığını söylenebiliriz. Öğretmen yetiştirme sisteminde 2006 yılından sonra bazı değişiklikler yapılarak, üniversitelerin öğretmen yetiştiren programlarında bazı dersler eklenerek öğrencilerin seçmeli derslerdeki farklı içerikli dersleri seçebilme olanakları artırılmıştır. Yapılan bu değişikliklerle öğretmen adaylarının gördükleri ders programları çeşitlendirilerek değiştirilmiş ve bu değişiklilerle de öğretmen adaylarının birden fazla, birbirinden farklı becerilere sahip olarak mezun olmaları hedeflenmiştir.

Öğretmen, eğitim hedefleri doğrultusunda belirlenmiş olan istendik davranışların bireylere kazandırılmasında çok önemli bir yere sahiptir. Öyle ki öğretmen, toplumu oluşturan insan tipini meydana getirilmesi sürecinde de önemli görev üstlenir (Oral, 1997). Öğretmen; öğrenciyi geleceğe hazırlayan, öğretilen bilginin yararlı davranışlara dönüşmesinde önemli bir öncü olma sorumluluğunu üstlenen kişidir (Yağmur, 2005). Bu durumda öğretmenin öğrenme sürecindeki bilgi kazanımının devamlılığı bireyler üzerinde oluşturacağ 1 etki ile doğrudan ilişkilidir. Öğretmen adaylarının lisans eğitimleri sürecinde kazandıkları öğrenmelerin meslek sürecindeki yıllar içerisinde değişmelerden ve gelişmelerden bağımsız kalması, öğrencilerinin günün değişim ve gelişmelerine ayak uyduramamasina neden olabilecektir. Buradan hareketle denilebilir ki öğretmenlerin mesleklerini icra ettikleri süreçte öğrenmeyi devam ettirmeleri oldukça önemlidir. Zira eğitim-öğretim sürecinde sadece fiziki olanakların artırılması nitelikli bir öğrenmenin olması için yeterli olamamaktadır.

Bursalığlu'nun da ifade ettiği (1994: 41), bir sosyal sistem olan okulun en stratejik öğelerinden biri öğretmendir. Öğretmenin sahip olduğu bilgi ve duygu durumu, onun öğrencilerle olan iletişiminin de niteliğini belirleyecektir. İyi bir iletişim, doğal olarak öğretmenin öğrenci üzerindeki öğrenmeye olumlu yönde katk1 sağlayacaktır. Eğitim-Öğretim sürecinde, öğretmenin sahip olduğu tutumların niteliği oldukça önemlidir. Yapılan araştırmalar incelendiğinde öğretmenlerin öğrenmeye ve öğretmenlik mesleğine ilişkin tutumlarını inceleyen çalışmaların çok az sayıda olduğu görülmüştür. Yapılan çalışmaların çoğunun aday öğretmenler üzerinde yapıldığı görülmüştür (Çetin, 2003; Erkuş, Sanl1, Bağl1 ve Güven, 2000).

Öğretmenler mesleklerini sürdürme süreci içerisinde, çocuklara yetişkin olma yolunda rehberlik, olumlu davranış ve tutum edinmelerinde örnek olmakla yanısıra MEB'in hedeflerini gerçekleştirmede de oldukça önemli bir role sahiptirler. Öğretmenlerin, örnek olabilmesi ve rehberlik yapabilmesi için kendilerinin de örnek davranışlara ve tutumlara sahip olmaları gerekir. Öyle ki, öğretmenler geleceğe olumlu bakan, öğrenmelerden olumlu yönde gelişme sağlayıcı beklentilere sahip olan ve yeni öğrenmelere sürekli açık olan örnek bir öğretmen profili çizmelidirler. Çünkü olumlu tutum sahibi öğretmenlerin, 
öğrencilerinin de olumlu tutum sahibi olmalarını sağlayabilir.

Bir diğer taraftan öğretmenlerin öğretmenlik mesleğine ilişkin tutumlarının nasıl olduğu mesleki niteliklerinin de nasıl olacağını belirlemede etkili olacaktır. Buradan hareketle denilebilir ki, öğretmenlerin mesleklerine ilişkin tutumlarının ne olduğu ve nasıl şekillendiğinin biliniyor olması, öğrencilerin ne düzeyde öğrenme ve davranış kazanacaklarını belirleyecektir. Her canlının çevresine gösterdiği tepkilerin zaman içerisinde çeşitli nedenlerle değiştiği bilinen bir durumdur. Öğretmenlerin de öğrenmeye ve öğretmenlik mesleğine ilişkin tutumları zamanla değişebilmekte ve söz konusu değişme çeşitli nedenlerden ötürü olumsuzlaşabilir. $\mathrm{Bu}$ durumda öğretmenlerin mesleklerini yürüttükleri yıllar içinde öğrenmeye ve öğretmenlik mesleğine ilişkin tutumlarının biliniyor olmasının önemi açıktır. Oysaki bu konuda yapılan çalışmalar incelendiğinde, yapılan araştırmaların çoğunlukla öğretmen adaylarının öğretmenlik mesleğine ilişkin tutumlarını tespit etmeye yönelik olduğu görülmektedir.

\section{Araştırmanın Amacı}

$\mathrm{Bu}$ araştırmada ortaöğretim okullarında görev yapan öğretmenlerin öğrenmeye ve öğretmenlik mesleğine ilişkin tutumlarının tespit edilerek, öğrenme ve öğretmenlik mesleğine ilişkin tutumlarının geliştirilmesine katkı sağlanması amaçlanmıştır. Bu amaç doğrultusunda; Ortaöğretim okullarında görev yapan öğretmenlerin; A) Öğrenmeye ve B) Öğretmenlik mesleğine ilişkin tutumlarında: 1.Mesleki kıdemleri, 2.Eğitim düzeyleri ve 3.İş doyum düzeylerine göre anlamlı farklılık var mıdır? Ayrıca Ortaöğretim öğretmenlerinin öğrenmeye ilişkin tutumları ile öğretmenlik mesleğine ilişkin tutumları arasında istatistiksel açıdan anlamlı düzeyde bir ilişki var mıdır? sorularına cevap aranmıştır.

\section{Araştırmanın Önemi}

İlgili alanın taranması sonucunda yapılan çalışmaların çoğunlukla öğretmen adaylarının öğretmenlik mesleğine ilişkin tutumlarının incelenmesi üzerine yapıldığı görülmüştür (Baykara Pehlivan, 2008; Bozdoğan, Aydın ve Yıldırım, 2007; Can, 1987; Çapri ve Çelikkaleli, 2008; Çetin, 2003; Demirtaş ve Özer, 2011; Güdek, 2007; Özder, Konedralı ve Zeki, 2010; Sağlam, 2008; Semerci, 2008; Şimşek, 2005; Temizkan, 2008; Terzi ve Tezci, 2007). Oysaki aday öğretmenlerin yanında süreç içerisinde sorumluluk taşıyan ve mesleklerini fiilen yapan öğretmenlerin, öğretmenlik mesleğine ilişkin tutumlarının incelenmesinin de eğitim niteliğinin artırılmasına katkı sağlayacağı düşünülmektedir.

Türkiye'de ortaöğretim öğretmenlerinin öğrenmeye ve öğretmenlik mesleğine ilişkin tutumlarını birlikte inceleyen herhangi bir araştırmaya rastlanılmamıştır. Öğretmenlerin öğrenmeye ve öğretmenlik mesleğine ilişkin tutumlarının, öğretmenlik mesleği açısından önemli bir yere sahiptir. Öğretmenlik mesleği 
temel hedef olarak bilgi, davranış ve duygu kazanımını esas alan ve bu hedefi uzun yıllar içerisinde kazandırmayı sağlayabilen bir meslektir. Öğretmenlerin yükseköğretim programından mezun olduktan sonra mesleklerini icra ederken öğrenmeye ve öğretmenlik mesleğine ilişkin sahip oldukları tutumlarda da değişmeler olabilmektedir. Böylece öğretmenlerin öğrenmeye ve öğretmenlik mesleğine ilişkin tutumlarının bilinmesinin önem arz etmektedir. Öğretmen faktörü bir bütün olarak değerlendirildiğinde, öğrenmeye ve öğretmenlik mesleğine ilişkin sahip olunan tutumun da bütün olarak incelenmesi ve öğretmenlerin hem öğrenmeye hem de öğretmenlik mesleğine ilişkin tutumlarının birlikte değerlendirilmesinin gerektiği düşünülmektedir.

$\mathrm{Bu}$ araştırmanın, ortaöğretim öğretmenlerinin öğrenmeye ve öğretmenlik mesleğine ilişkin tutumlarının birlikte incelendiği ilk çalışma olması nedeniyle alana katkı sağlaması umulmaktadır.

\section{Araştırmanın sınırlııkları}

$\mathrm{Bu}$ çalışma; Malatya merkez ilçeleri, Yeşilyurt ve Battalgazi'de bulunan ortaöğretim okullarında görev yapan öğretmenlerle, kullanılan öğretmenlik mesleğine ilişkin ve öğrenmeye ilişkin tutum ölçekleri ile sınırlandırılmıştır. Bu araştırma ayrıca; 2019-2020 eğitim öğretim yılının birinci yarıyılında ilgili İlçelerde görev yapan öğretmenler ve tabakalama yöntemiyle belirlenen 588 öğretmenle sinırlıdır.

\section{KURAMSAL ÇERÇEVE ve İLGILİ ARAŞTIRMALAR}

Öğretmenlik mesleğinin niteliklerinin, öğrenme içeriklerinin ve öğretim niteliğinin ne olduğu, nasıl olması gerektiği ile ilgili sürekli tartışmaların yapıldığı Türkiye'de, ortaöğretim öğretmenlerinin hem öğrenmeye hem de öğretmenlik mesleği hakkındaki tutumlarına dair çalışmaların neredeyse tümünün öğretmen adayları üzerinde yapıldığı görülmektedir.

\section{Öğrenme ve Öğrenmeye ilişkin Tutumlar}

Yapılan incelemeler sonucunda öğrenme kavramı hakkında araştırmacılar ve uygulayıcılar tarafından evrensel anlamda kabul görmüş genel geçer bir tanımının olmadığ1 görülmemekle birlikte (Schunk, 2009; Özdemir, 2015), öğrenmeyi, birden çok görülen ve yaşanmışlıklardan sonra davranışlarda görülen kalıcılığı yüksek, sürekli farklılaşmalar barındıran bir süreç şeklinde olduğu genel bir kabul görmektedir. Özden'e (2000) göre öğrenme, çevrede oluşan farklılıklardan dolayı bireylerin duygularında, düşüncelerinde ve ifade biçimlerinde meydana gelen değişmelerdir. İnsanoğlunun hayatta kalabilmesi için gerekli olan en önemli kazanımlardan biri de yaşadığ sağlayabilme becerisidir. Bu durumda denebilir ki, öğrenme insanoğlu için 
hayatta kalabilmenin temel bir unsurudur. Bu temel unsur, kalıcı olduğu oranda öğrenme gerçekleşmiştir denilebilir.

Literatür incelendiğinde: Öğrenme, kişilerin doğumundan ölümüne kadar, hayatlarının her anını kuşatan bir süreçtir (Gündoğan, 2003). Başka bir ifadeyle ögrenme, bireylerin mevcut halleri ile yapamadıkları bir iş, eylem, düşünce vb. olgu ve olayları belirli bir deneyim sonrasında yapabiliyor olması olarak tanımlanabilir (Kara, 2010: 32). Öğrenme, davranışlarda kalıcılık gösteren ve yaşantılarımızın ürünü olan değişimlerdir (Demirel, 2012). Arı' ya (2011) göre ögrenme, bilgi ve yeteneklerin kazanılması süreci veya insanoğlunun tutumların da değişikliklere neden olan yeni bilgi ve anlama yeteneği oluşturma sürecidir. Öğrenme, bireyin yaşamının bir ürünü olmasıyla beraber oldukça süreklilik gösteren davranış değişimleridir (Duman, 2008). Öğrenme, her bireyin doğumu ile başlayan ve ölümüne kadar devam eden bir süreçtir (Gündoğan, 2003). Öğrenme, bir anlamda eğitimin özünü oluşturur. İnsanlık var olduğu günden beri her zaman değişmenin ve gelişmenin bir aracı olmuştur. Günümüzde her türlü konuya ve değişime çabucak uyum sağlamak insanoğlunun en önemli gelişimsel özelliği haline gelmiştir (Kara, İzci ve Ulutaş, 2011: 988). Meydana gelen her değişme ya da gelişme öğrenmeyle ancak sağlanabilir. İstenilen düzeyde öğrenmelerin gerçekleşebilmesi için önemli bir faktörün de tutumlar olduğu bilinmektedir. Öğrenen kişinin öğrenmeye ilişkin hangi tutumun içerisinde olduğu önemlidir. Çünkü insanların herhangi bir bilinmeyeni bilmeye yani öğrenmeye dair sahip olduğu biçim öğrenme ile ortaya çıkacak olan ürünlerin nasıl olacağına da etki edecektir. İnsanların öğrenmeye karşı sahip oldukları olumlu tutumun öğrenme konusunda daha iyi bir performans sergilemelerine neden olduğu görülmüştür (Kara, Tekin, Ünişen ve İzci 2016: 56)

İlgili literatür incelendiğinde tutum ile ilgili bir çok tanımın yapılmış olduğu görülmektedir. Turgut (1992) tutumu; Duygu, düşünce ve davranış birlikteliği olarak tanımlamaktadır. Başka bir tanımda tutum; Bir kişiye uygun görülen bir eğilim olarak tanımlanmakta olup, tutumu bir davranış olmaktan çok, davranış öncesi hazırlık özelliği gösteren bir etken olduğu ifade edilmektedir (Arkonaç, 1998). Canakay, (2006)'a göre; Düşünce ve davranışların oluşmasında tutumlar önemli bir yer tutmakta dolaysıyla da başarıyı yakalamak için kişilerin olumlu tutumlara sahip olması gerekir. Yapılan tanımlamalardan da anlaşılmaktadır ki, sahip olunan tutumun ne olduğu, sahip olunmak istenen amacin nasıl olacağını ya da olup olamayacağını belirleyen önemli bir etkendir.

Dinamik bir süreç olan eğitim-öğretim faaliyetlerinin temel aktörü konumundaki öğretmenlerin sahip oldukları tutumların bilimsel araştırmalar sonucunda tespit edilmesi ve bunun ortaya konması, hızla değişen ve gelişen eğitim-öğretim alanında hedeflenen gelişmişlik düzeyinin yakalanması açısından yararlı olacaktır. Öğrencilere örnek oldukları ve taklit edilen insanlar oldukları 
dikkate alındığında bu araştırmada öğretmenlerin öğrenmeye ilişkin tutumlarının belirlenmesi eğitim sisteminin hem uygulama boyutunda hem de program geliştirme açısından oldukça önemlidir.

\section{Öğretmenlik Mesleği ve Öğretmenlik Mesleğine İlişkin Tutumlar}

Günümüzde öğretmen, eğitim fakültelerinin herhangi bir programını tamamlayarak, ya da eğitim fakültesinin dışında lisans mezunu olanların pedagojik formasyon sertifika programını tamamlayarak yetkinliğini gösteren diploma ile öğretmenlik mesleğini yapmaya yetkili olan kimsedir. Öğretmenlik mesleği sadece günün değil aynı zamanda gelecekteki nesillerin nasıl olacağına etki yapabilen bir özelliğe sahiptir. Gelecek nesillerin niteliği onu yetiştiren öğretmenlerin niteliği ile belirginleşecektir. Çocuklar aileden sonra ilk kez sosyal bir topluluk olan sınıf ile tanışır ve öğretmeni rol model alır. Öğretmenin kişilik özellikleri öğrencilerin kişiliklerinin şekillenmesinde oldukça önem taşır (Dăğ, 2010). Öğretmen, kişiliğin şekillenmesinde belirleyici olan bir meslek sahibi, zanaatkârdır (Çelikten ve diğerleri, 2005). Yazıcı'ya (2009) göre, öğretmenlik mesleğini tercih edenlerin bu mesleğin gerektirdiği temel özelliklere sahip olmaları gerekmektedir. Bu özelliklerin kişisel yönü olmakla birlikte, okul eğitimi ve entelektüel yönünün de olduğu ifade edilmektedir. Öğretmen bilgiyi aktaran olmakla beraber, davranışı, duygu ve tutumları da belirleyici bir konuma sahip olan önemli bir aktördür.

Öğretmenler meslekleri icra ederken, mesleklerine dair kabullendikleri tutumları büyük önem taşınmaktadır. Araştırmacılar, yaptıkları çalışmaların sonucunda öğretmenlerin mesleklerini yaparken meslekleri hakkında pozitif bir tutum içerisinde olmaları durumunun onların iş doyumlarının da üst düzeyde olmasını sağladığını gördüklerini ifade etmektedirler (Tanrıöğen, 1997). Çalışma alanında iş doyumunun üst düzeyde olmasının beraberinde, öğretmenlerde mesleki gelişimi önemsemeyi ve çevreleri ile sağ lkklı ve verimli ilişkiler kurmayı sağladığı pek çok araştırmacı tarafından tespit edilmiştir (Ertürk, ve Keçecioğlu, 2012; Kılıç, 2011; Kumaş ve Deniz, 2010; Sarıkaya, 2019). Öğretmenin sahip olduğu tutum özelliklerinin önemsenmemesi durumunda, sağlıklı bir eğitimöğretim ortamının oluşması ve sürdürülebilir öğrenme yaşantılarının meydana getirilmesinin pek mümkün olamayacağı unutulmamalıdır (Sözer, 1996: 8-9).

Öğretmenlerin eğitim ortamlarında öğrencilerle olan etkileşimleri ve eğitim ortamları dışında da yine öğrenci ve velileri ile olan ilişki ve etkileşimleri, öğrenci tutumlarının oluşmasında belirgin bir şekilde etkili olmaktadır. Zira öğrenci ve öğretmen arasında olumlu ilişkilerin olması ve bunun sürdürülebilmesi, öğrencilerin gelecekte toplumsal ilişkilerinde yetişkinlerle olumlu tutum içinde olmalarını sağlayacaktır (Ülgen, 1997: 93). Öğretmenlerin gerek öğrencilere ve gerekse okul etkinliklerine gösterdikleri tutum biçimlerinin öğrencilerin öğrenme 
ve kişilik gelişimlerine etkisi olduğu da bilinmektedir. Küçükahmet (1976)'e göre tutum, öğretmenlerin sahip olduğu en önemli kişilik özelliklerinden biri olup öğrenciler üzerinde etki bırakan bir etmendir. Her ne kadar bireylerin kendilerine özgü tutumlarının kendi hayatlarını etkilediği biliniyor olsa da kendilerinin dışındakilerin de hayatlarını etkiledikleri bilinmektedir (Fındıkçı, 1991: 92-93).

Öğretmenler sahip oldukları tutumlarla geleceği şekillendirecek olan öğrencilerin kişilik özelliklerini etkiledikleri gibi, eğitim ve öğretime ilişkin geliştirecekleri tutumları da etkilemektedirler. Yapılan bazı araştırmalar, öğrencilerin akademik başarısızlıklarının nedenlerinden birisinin de, öğretmen tutumları olduğunu göstermektedir (Gürkan, 1993). Olumsuz öğretmen tutumlarının, öğretmenlik mesleğini tercih etme aşamasında başladığını ifade eden araştırmaların olduğu da görülmekle birlikte (Murat, Ünişen ve Kanadl, 2010: 226-244), üniversitelerin öğretmen adaylarına lisans eğitimleri sürecinde öğretmenlik mesleğine ilişkin olumlu tutum kazandırmada yetersiz kaldıklarını ifade eden çalışmalar da görülmüştür (Çakır, 2005; Duatepe ve Akkuş-Çıkla, 2004; Recepoğlu, 2013; Yalız, 2010). Öğretmenlerin üniversitede alınan eğitimle yetinmelerinin meslek sürecinde meydana gelen değişmelere ve gelişmelere uyum sağlayabilmelerini zorlaştıracağını dolaysıyla da öğretmenlere nitelikli hizmet içi eğitimlerin verilmesi gerektiği belirtilmiştir (İzci ve Kara, 2010: 161168). Öğretmenlerin mesleklerine ilişkin olumlu tutum içerisinde olmalarının, ülkelerin eğitim hedeflerinin gerçekleştirilmesinde çok önemli olduğu bilinmektedir. Nitelikli öğrenme ve öğretme süreçlerinin oluşması, istenmeyen davranış biçimlerinin en aza düşürülmesi için öğretmen tutumlarının önemsenmesi kalıcı, etkili öğrenme ve davranışların kazandırılması bakımından çok önemlidir.

Buradan hareketle denilebilir ki; Öğretmenlerin, öğretmenlik mesleğine ilişkin tutumlarının bilinmesi ve gerekli bilimsel iyileştirmelerin yapılmasının eğitimde istenilen düzeyi yakalamak için faydalı olacağı düşünülmektedir.

\section{İlgili Literatür}

Türkiye'de ortaöğretim öğretmenlerinin öğrenmeye ve öğretmenlik mesleğine ilişkin tutumları konusunda herhangi bir araştırmaya rastlanılmamıştır. Ancak literatürün incelenmesi sonucunda yapılan çalışmaların büyük çoğunluğunun öğretmenliğe kaynak oluşturan çeşitli programlarda okumakta olanların öğretmenlik mesleğine ilişkin tutumlarının araştırılması ile ilgili olduğu görülmüştür (Baykara Pehlivan, 2008; Bilgin, 1996; Bozdoğan, Aydın ve Yıldırım, 2007; Can, 1987; Çapri ve Çelikkaleli, 2008; Çetin, 2003; Demirtaş ve Özer, 2011; Güdek, 2007; Özder, Konedralı ve Zeki,2010; Sağlam, 2008; Semerci, 2008; Şimşek, 2005; Temizkan, 2008; Terzi ve Tezci, 2007). 
Yapılan çalışmalar incelendiğinde öğretmen adaylarının özgüvenleri öğretmenlik mesleğine ilişkin tutumlarını olumlu etkilendiği (Can ve Özcan, 2016), cinsiyet, kıdem, branş, mezun oldukları okul türü ve çalışmakta oldukları ilköğretim kademesi gibi değişkenlerin öğretmenlerin mesleğe yönelik görüşlerini etkilemediği (Kara, İzci ve Ulutaş, 2011; Özder, Konedralı ve Zeki, 2010; Tanel vd., 2007) sonucuna varılmıştır. Öğretmen adaylarının öğretmenlik mesleğine ilişkin tutumlarının cinsiyetleri ve bölümü tercih etmedeki nedene ya da lise türüne göre manidar ilişki olduğu görülmüştür (Aktürk, 2012; Bozdoğan, Aydın ve Yıldırım, 2007; Gürbüz ve Kışoğlu, 2007; Gürbüztürk ve Genç, 2004; Çetin, 2003; Sütçü, 1997). Bazı çalışmalarda ise öğretmen adaylarının öğretmenlik mesleğine yönelik tutumlarının cinsiyet anlamında farklılık olduğu, kız öğrencilerin erkek öğrencilere oranla daha fazla olumlu tutumlara sahip olduğu, mezun olunan lise türlerinin öğretmenlik mesleğine ilişkin tutum üzerinde belirleyici olduğu tespit edilmiştir (Çetin, 2003; Çapa ve Çil, 2000; Soran vd., 1996).

Yurtdışındaki çalışmalarda ise; kadın öğretmenlerin erkek öğretmenlere göre, k1demli öğretmenlerin genç öğretmenlere göre öğretmenlik mesleğine ilişkin daha olumlu bir tutum içerisinde oldukları (Malsawmi ve Renthlei, 2015), iş doyumlarının da olumlu tutumlara neden olduğu (Wilson, 2008; Osunde ve Izevbigie, 2006), öğretmenlerin istekli, neşeli ve dinamik davranışlarının öğrenci başarısı üzerinde olumlu sonuçlar meydana getirdiği (Rosnow ve Rosenthal, 1997; Garfield, 1973) de görülmüştür.

Öğretme-öğrenmeye ilişkin tutumlar ile ilgili yurt içinde yapılan çalışmalara az rastlanılmıştır. Bu araştırmaların daha çok öğretmenliğe kaynak teşkil eden yükseköğretim programlarında okumakta olan öğrencilerle yapıldığı ve genellikle öğrenmeye ilişkin sahip olunan güdüler, öğrenme stratejileri ve öğrenme stilleri ile ilgili olduğu görülmektedir (Çakmak, Akgün, Karadeniz, Büyüköztürk ve Demirel, 2008; Çelik, Yıldırım, Batur, Çime, Çapraz, Kubat, 2014; Güven ve Kürüm, 2006; Kaya ve Akçin, 2002). Yurtdışında ise öğrenmeye ilişkin tutumların incelendiği araştırmalarda öğretmenlerin öğrenme öğretme anlayışlarının mesleklerinin ilk yıllarında öğretmen merkezli anlayışa sahip olduğu fakat süreç içerisinde öğrenci merkezli anlayışa doğru değişme gösterdiği (Tigchelaar, Vermunt ve Brouwer, 2014; Krull, Koni ve Oras, 2013; Chan ve Elliott, 2004); yaş, cinsiyet ve anabilim dalı değişkenlerinin öğrenme - öğretme anlayışını etkilemediği fakat mensubu olunan ırkın öğrenme - öğretme anlayışlarında değişiklik oluşturduğu (Chan, Tan ve Khoo, 2007; Hancock ve Gallard, 2004) görülmüştür. Ayrıca dersi öğrenmeye ilişkin olumlu tutumların akademik başarıda etkili olduğu da belirlenmiştir (Rula, 2006).

$\mathrm{Bu}$ araştırmanın, öğretmenlerin öğrenmeye ve öğretmenlik mesleğine ilişkin tutumlarını birlikte ele alarak incelemesi, çalışmaya katılanların aktif olarak 
görevlerinde olan lise öğretmenleri olması ve lise öğretmenlerinin öğrenmeye ve öğretmenlik mesleğine ilişkin tutumlarını nicel bulgularla ortaya çıkarmayı hedeflemesi açısından özgün bir çalışma niteliğine sahiptir.

\section{YÖNTEM}

\section{Araştırmanın Modeli}

Ortaöğretim öğretmenlerinin öğrenmeye ve öğretmenlik mesleğine ilişkin tutumlarının incelendiği bu çalışmada, verileri elde etmek amacıyla ilişkisel tarama modelinde, nicel araştırma yöntemi kullanılmıştır. Karasar (2005) tarama modelini, araştırmalarda gerek geçmişte gerekse günümüzde var olan her tür durumu var olduğu şekliyle betimlemek için genellikle geniş bir kitleden araştırmacı tarafından bilgi toplamayı amaçlayan araştırma yaklaşımı olarak tanımlamıştır.

\section{Araştırmanın Evreni ve Örneklemi}

Araştırmanın evrenini Malatya İlinin Yeşilyurt ve Battalgazi ilçelerinde bulunan ortaöğretim okullarında görev yapan yaklaşık 2950 öğretmen oluşturmaktadır. Hazırlanan ölçekler kolay erişilebilirlik yöntemiyle toplam 1200 öğretmene bizzat araştırmacı tarafından dağıtılmıştır. Geri dönüşü sağlanan 588 öğretmen araştırmanın evrenini temsil etmiştir. Uygulama 2018-2019 eğitim öğretim y1lı 2. döneminde başlanmış ve 2019-2020 eğitim öğretim yılının birinci yarıyılında tamamlanmıştır. Araştırmada örneklemin tespit edilmesi için seçkisiz örnekleme yöntemlerinden biri olan tabakalı örnekleme kullanılmıştır.

Araştırmaya katılan öğretmenlerin \%44,2'si ( $\mathrm{n}=260)$ kadın, 55,8' $\mathrm{i}(\mathrm{n}=328)$ ise erkektir, öğretmenlerin (\%23.1'i $(n=136)$ 1-5 y1l, \%24.5' $\mathrm{i}(\mathrm{n}=144) \quad 6-10$ y11, \%17.7'si (n=104) 11-15 yı1, \%19.4'ü $(n=114) 16-20$ y11, \%15.3ü $(n=90)$ ise 20 ve üzeri yıl mesleki kıdeme sahiptir. Araştırmaya katılan öğretmenlerin \%54.3'ü $(\mathrm{n}=319)$ eğitim fakültesinden mezun, \%8.7'si $(\mathrm{n}=51)$ eğitim enstitüsü mezunu, $\% 29.1$ 'i $(\mathrm{n}=171)$ fen edebiyat fakültesinden mezun, \%8.0'1 $(\mathrm{n}=47)$ diğer fakültelerden mezun olmuştur. Araştırmaya katılan öğretmenlerin \%10.9'u $(\mathrm{n}=64)$ düşük iş doyumuna, $\% 46.9$ ' $\mathrm{u}(\mathrm{n}=276)$ orta düzeyde iş doyumuna ve $\% 42,2$ 'si (n=248) yüksek düzeyde iş doyumuna sahip olduklarını ifade etmişlerdir.

\section{Veri Toplama Araçları}

Ortaöğretim öğretmenlerinin öğrenmeye ve öğretmenlik mesleğine ilişkin tutumlarının incelenmesi amacıyla gerçekleştirilen bu araştırmada iki veri toplama aracına ihtiyaç duyulmuştur. Birinci veri toplama aracı; Kara (2010) tarafından geliştirilmiş olan “Öğrenmeye İlişkin Tutum Ölçeği”dir. İkinci veri 
toplama aracı ise, Demirel ve Ünişen (2018) tarafindan geliştirilmiş olan "Öğretmenlerin Öğretmenlik Mesleğine İlişkin Tutum Ölçeği" dir.

Öğrenmeye ilişkin tutumu ölçmek için Kara (2010) tarafindan geliştirilen “Öğrenmeye İlişkin Tutum Ölçeği” kullanılmıştır. Dört alt boyuttan oluşan ölçek (Öğrenmenin doğası, öğrenmeden beklentileri, öğrenmeye ilişkin kaygı ve öğrenmeye açıklık) toplam 40 madde içermekte ve beş seçenekten oluşmaktadır (5 "Katıllyorum" ile 1 "Hiç Katılmıyorum").

İkinci veri toplama aracı öğretmenlik mesleğini icra eden öğretmenlerin mesleğe ilişkin tutumlarını belirlemek amacıyla Demirel ve Ünişen (2018) tarafından geliştirilen "Öğretmenlerin Öğretmenlik Mesleğine İlişkin Tutum Ölçeğì" kullanılmıştır. Beşli likert tipi ölçek niteliği taşıyan ölçeğin "Değer verme, Mesleki tükenmişlik, İlgisizlik ve Mesleki gelişime açıklık” olmak üzere dört alt boyuttan oluşmaktadır.

\section{Verilerin Analizi}

1200 öğretmenden geri dönüş yapanlar içerisinde eksik veri, mükerrer yanıtlar vb. hususlardan dikkate alınmayan ölçekler çıkarılınca 588 öğretmene uygulanmış ve uygulama sonucunda toplanan veriler bilgisayar destekli programla incelenmiştir. İlgili ölçeklerin örnekleme uygulaması sonucunda öğrenmeye ilişkin tutum ölçeğinin güvenirlik katsayısının (KMO) 0,90 ve öğretmenlik mesleğine ilişkin tutum ölçeğinin değerinin ise 0,93 olduğu dolaysıyla da her iki ölçeğin de güvenilir veriler topladıkları görülmüştür. Öğretmenlerin ölçeklere ilişkin verdikleri yanıtların çeşitli değişkenler açısından farklılaşıp farklılaşmadığını belirlemek için öncelikle bağımlı değişkenlere ait puanların dağılımlarının her bir bağımsız değişkenin alt gruplarında normal dağ $11 ı m ı$ çarpıklık ve basıklık katsayıları ile belirlenmiştir. Elde edilen sonuçlarda çarpıklık ve basıklık katsayılarının \pm 1 aralığında kaldığ 1 durumlarda fark analizi parametrik testler (bağımsız gruplar t testi ve tek yönlü Anova testi) kullanılırken, \pm 1 aralığın dişına çıktığı durumlarda ise non-parametrik testler (Mann Whitney U testi ve Kruskall Wallis $H$ testi) kullanılmıştır. Araştırmada öğretmenlerin öğrenmeye ilişkin tutumları ile öğretmenlik mesleğine ilişkin tutumlar arasındaki ilişkinin test sonuçları yorumlanırken " $0,01-0,30=$ Düşük; $0,31-0,70=$ Orta; $0,71-1,00=$ Yüksek düzeyde bir ilişki” aralıklar dikkate alınmıştır (Büyüköztürk, 2014: 32).

\section{BULGULAR VE YORUM}

\section{Öğretmenlerin Kıdemleri Açısından Bulgular ve Yorum}


Araştırmanın birinci alt probleminde öğretmenlerin öğrenmeye ve öğretmenlik mesleğine ilişkin tutumlarında kıdemleri açısından anlamlı farkın olup olmadığını belirlemek için yapılan Anova ve Kruskall Wallis testi sonuçları aşağıdaki tablolarda özetlenmiştir (Sadece anlamlı bulunan verilere yer verilmiştir).

Tablo 1. Mesleki Kıdem Açısından Öğretmenlik mesleğine ilgisizlik alt boyutuna ilişkin Anova Testi Sonuçları

\begin{tabular}{|c|c|c|c|c|c|c|c|c|c|}
\hline & $\mathrm{N}$ & Ort. & SS & $\begin{array}{c}\text { Varyansın } \\
\text { kaynağ }\end{array}$ & KT & $\mathrm{Sd}$ & KO & $\mathrm{F}$ & $\mathrm{p}$ \\
\hline $5 \times 1$ & 136 & 18 & & Gruplararası & 164,907 & 4 & 41,227 & 2,927 & ,020 \\
\hline $6-10$ & 144 & 18,3 & 3,7 & Gruplariçi & 8210,663 & 583 & 14,083 & & \\
\hline $11-15$ y1l & 104 & 18,30 & 4,07 & Toplam & 8375,570 & 587 & & & \\
\hline
\end{tabular}

16-20 yıl $\quad 114 \quad 18,753,75$

21 yıl ve üstü $90 \quad 19,91 \quad 3,47$

$\begin{array}{llll}\text { Toplam } \quad 588 \quad 18,78 & 3,77\end{array}$

6-10 yıl ile 21 yıl ve üstü

Yukarıdaki bulguların analizinde, öğretmenlerin mesleki kıdemler bakımından mesleğe ilişkin ilgisizlik alt boyutunda puan ortalamalarındaki farkların anlamlı olduğu görülmüştür $(F=2,927 ; p<0,05)$. Söz konusu bu farkların hangi gruplar arasında olduğu belirlemek için homojenlik testinin sonucuna göre Bonferroni testi uygulanmış ve 21 yıl ve üstü kıdeme sahip olan öğretmenler 615 yıl arasında kıdeme sahip olanlardan anlamlı düzeyde daha yüksek puan ortalamalarına sahip oldukları görülmüştür $\left(\operatorname{Ort}_{6-10}=18,36\right.$; Ort $_{11-15 y 1}=18,30$; $\operatorname{Ort}_{21}$ yıl ve üstü=19,91). Buna göre 21 y1l ve daha fazla k1deme sahip olan öğretmenler 615 yıl aralığında mesleki kıdem sahibi öğretmenlerden mesleğe daha fazla ilgisizlik duydukları görülmüştür.

Normal dağılım görülmediği alt boyutlarda uygulanan Kruskall Wallis $\mathrm{H}$ testinin sonuçlarına göre ise öğrenmeden beklentiler alt boyutunda öğretmenlerin kıdemleri açısından sıra ortalamaları arasındaki farkların anlamlı olduğu görülmüştür $(H=11,232 ; \mathrm{p}<0,05)$. Söz konusu bu farkların hangi gruplar arasında olduğunu belirlemek için ikili karşılaş̧ırmalar yapılmış ve 1-5 yıl ile 6-10 yıl arasında kıdeme sahip olan öğretmenler anlamlı düzeyde öğrenmeden daha fazla beklenti içerisinde oldukları görülmüştür.

Öğrenmeye açılklı alt boyutunda da öğretmenlerin kıdemleri açısından sıra ortalamaları arasındaki farklar anlamlı çıkmıştır $(\mathrm{H}=15,374 ; \mathrm{p}<0,05)$. İkili karşılaştırmalara göre 1-5 y1l ile 6-10 yıl arasında kıdeme sahip olan öğretmenlerin 11 yıl ve daha fazla kıdeme sahip olan öğretmenlerden anlamlı düzeyde öğrenmeye daha açık oldukları bulgusuna ulaşılmıştır.

Öğretmenlik mesleğine değer verme alt boyutunda öğretmenlerin kıdemleri açısından sıra ortalamaları arasındaki farklar anlamlı çıkmıştır $(H=9,830$; 
$\mathrm{p}<0,05)$. İkili karşılaştırmalara göre mesleğin başında öğretmenlik mesleğine değer verilirken kıdem ilerledikçe bir azalma görülmekte mesleğin sonlarına doğru değer verme tutumu tekrar yükseldiği görülmektedir.

Mesleki gelişime açıklık alt boyutu incelendiğinde ise anlamlı çıkan farkların $(\mathrm{H}=10,409 ; \mathrm{p}<0,03)$ ikili karşılaştırmalara göre öğretmenlerin kıdemleri ilerledikçe mesleki gelişime açıklık 11-15 yıl arasında zirveye varırken daha sonraki yillarda tekrar düşüşe geçtiği görülmüştür.

Tablo 2. Mesleki Kıdem Açısından Kruskall Wallis Testi Sonuçları

\begin{tabular}{|c|c|c|c|c|c|c|c|}
\hline & $\begin{array}{l}\text { Mesleki } \\
\text { K1dem }\end{array}$ & $\mathrm{N}$ & $\begin{array}{l}\text { Sira } \\
\text { Ort. }\end{array}$ & $\begin{array}{l}\text { Kruskal- } \\
\text { Wallis H }\end{array}$ & $\mathrm{Sd}$ & $\mathrm{p}$ & Mann Whitney U \\
\hline Öğrenmeden & $1-5 \mathrm{y} 1 \mathrm{l}$ & 136 & 314,56 & 11,232 & 4 & ,024 & $1-5$ ile $16-20$ \\
\hline \multirow[t]{4}{*}{ Beklentiler } & $6-10$ yil & 144 & 318,76 & & & & 6-10 ile $11-15$ \\
\hline & $11-15$ y1l & 104 & 276,27 & & & & 6 -10 ile $16-20$ \\
\hline & $16-20$ y1l & 114 & 258,34 & & & & \\
\hline & 21 yıl ve üstü & 90 & 292,24 & & & & \\
\hline Öğrenmeye & $1-5$ y1l & 136 & 310,46 & 15,374 & 4 & ,004 & 1-5 ile $11-15$ \\
\hline \multirow[t]{4}{*}{ Açıklık } & 6-10 y1l & 144 & 329,18 & & & & 6-10 ile $11-15$ \\
\hline & $11-15$ y1l & 104 & 251,54 & & & & 6 -10 ile $16-20$ \\
\hline & $16-20$ y1l & 114 & 275,85 & & & & \\
\hline & 21 yıl ve üstü & 90 & 288,15 & & & & \\
\hline Değer & $1-5 \mathrm{y} 1 \mathrm{l}$ & 136 & 318,68 & 9,830 & 4 & ,043 & $1-5$ ile $6-10$ \\
\hline \multirow[t]{4}{*}{ Verme } & $6-10$ y1l & 144 & 277,26 & & & & 1-5 ile $11-15$ \\
\hline & $11-15$ y1l & 104 & 267,02 & & & & $6-10$ ile 21 ve + \\
\hline & $16-20$ y1l & 114 & 289,14 & & & & $11-15$ ile 21 ve + \\
\hline & 21 yıl ve üstü & 90 & 324,08 & & & & \\
\hline Mesleki & $1-5$ y1l & 136 & 273,31 & 10,409 & 4 & ,034 & 1-5 ile $11-15$ \\
\hline Gelişime & $6-10$ yil & 144 & 283,96 & & & & $1-5$ ile $16-20$ \\
\hline \multirow[t]{4}{*}{ Açıklık } & $11-15$ y1l & 104 & 326,58 & & & & 6-10 ile $11-15$ \\
\hline & $16-20$ y1l & 114 & 320,19 & & & & $11-15$ ile 21 ve + \\
\hline & 21 y1l ve üstü & 90 & 273,77 & & & & \\
\hline & Toplam & 588 & & & & & \\
\hline
\end{tabular}

\section{Öğretmenlerin Eğitim Düzeyi Açısından Bulgular ve Yorum}

Araştırmanın üçüncü alt probleminde öğretmenlerin öğrenmeye ve öğretmenlik mesleğine ilişkin tutumlarında eğitim düzeyi açısından anlamlı farkın olup olmadığını belirlemek için yapılan Anova ve Kruskall Wallis testi sonuçları aşağıdaki tablolarda özetlenmiştir.

Tablo 3. Eğitim Düzeyi Açısından Mesleki gelişime açıklık alt boyutuna ilişkin Anova Testi Sonuçları 


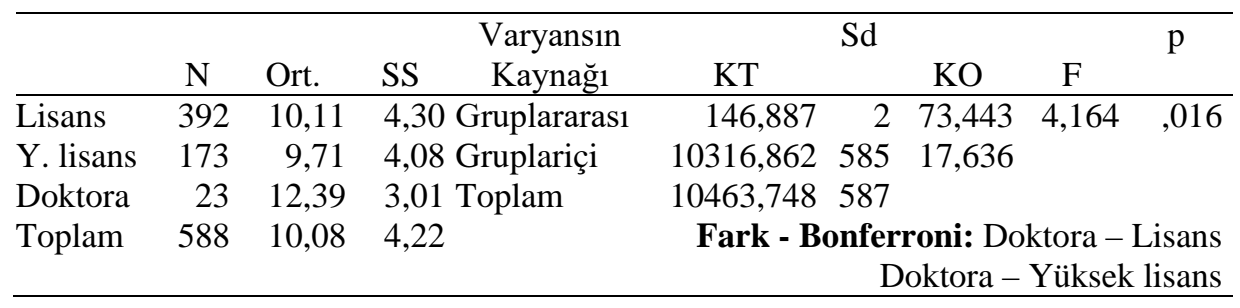

Yukarıdaki tablo incelendiğine öğretmenlerin eğitim düzeyi açısından öğrenmeye ilişkin tutumları ile öğretmenlik mesleğine ilişkin tutumları incelendiğinde sadece mesleki gelişime açıklık alt boyutunda puan ortalamalarındaki farklar anlamlı çıkmıştır $(F=4,164 ; p<0,05)$. Söz konusu bu farkların hangi gruplar arasında olduğu belirlemek için homojenlik testinin sonucuna göre (Levene $=2,804 ; \mathrm{p}=0,061$ ) Bonferroni testi uygulanmış, mesleki gelişime açılık alt boyutunda doktora düzeyinde mezun olan öğretmenlerin lisans ve yüksek lisans düzeyinde mezun olan öğretmenlerden anlamlı düzeyde daha yüksek puan ortalamalarına sahip oldukları görülmüştür $\left(\right.$ Ort $_{\text {Lisans }}=10,11$; Ort YüksekLisans $=9,71$; Ort $_{\text {Doktora }}=12,39$ ). Buna göre doktora düzeyinde mezun olan öğretmenlerin mesleki gelişime açıklık tutumlarının, lisans ve yüksek lisans düzeyinde mezun olan öğretmenlere göre daha yüksek olduğu görülmüştür.

Öğrenmenin doğası ve öğrenmeden beklentiler alt boyutlarında ise yapılan Kruskall Wallis testinin sonuçlarına göre her iki alt boyutlarında da öğretmenlerin eğitim düzeyleri açısından sıra ortalamaları arasındaki farkların anlamlı olduğu görülmüştür $\left(\mathrm{H}_{\text {öğr. doğası }}=6,669 ; \mathrm{p}<0,05 ; \mathrm{H}_{\text {ŏğr. beklentiler }}=6,319 ; \mathrm{p}<0,05\right)$. Söz konusu bu farkların hangi gruplar arasında olduğunu belirlemek için ikili karşılaştırmalar yapılmış ve doktora mezunu öğretmenler lisans ve yüksek lisans mezunu öğretmenlerden anlamlı düzeyde öğrenmenin doğasında ve öğrenmeden beklentiler hususunda daha düşük puanlara sahip oldukları görülmüştür. Araştırmaya katılan ortaöğretim öğretmenlerinden doktora mezunu olanlar, bu kademedeki eğitimin özellikleri etkileriyle tutumlarını biçimlendirdikleri, muhtemelen somut bilişlerin ötesine geçip meta bilişe yönelmeleriyle öğrenmenin doğasına; lisansüstü eğitimden beklentilerinin ideal benlik ve cebri benliklerine etkisiyle bu durumlarını olduğu gibi tüm öğrenmelerine yansitmalarına neden olduğu şeklinde yorumlanabilir.

Tablo 4 - Eğitimi Düzeyi Açısından Kruskall Wallis Testi Sonuçları

\begin{tabular}{|c|c|c|c|c|c|c|c|}
\hline & $\begin{array}{l}\text { Eğitim } \\
\text { Düzeyi }\end{array}$ & $\mathrm{N}$ & $\begin{array}{l}\text { Sira } \\
\text { Ort. }\end{array}$ & $\begin{array}{l}\text { Kruskall- } \\
\text { Wallis H }\end{array}$ & Sd & $\mathrm{p}$ & Mann Whitney U \\
\hline Öğrenmenin & Lisans & 392 & 300,37 & 6,669 & 2 & ,036 & Doktora - Lisans \\
\hline \multirow[t]{3}{*}{ Doğası } & Y. lisans & 173 & 292,90 & & & & Doktora - Y. lisans \\
\hline & Doktora & 23 & 206,52 & & & & \\
\hline & Lisans & 392 & 294,44 & 6,319 & 2 & ,042 & Doktora - Lisans \\
\hline
\end{tabular}




\begin{tabular}{llrrr} 
Öğrenmeden & Y. lisans & 173 & 305,73 & Doktora - Y. lisans \\
Beklentiler & Doktora & 23 & 211,04 & \\
& Toplam & 588 & & \\
\hline
\end{tabular}

\section{Öğretmenlerin İş Doyum Düzeyi Açısından Bulgular ve Yorum}

Araştırmanın dördüncü alt probleminde öğretmenlerin öğrenmeye ve öğretmenlik mesleğine ilişkin tutumlarında iş doyum düzeyi açısından anlamlı farkın olup olmadığını belirlemek için yapılan Anova ve Kruskal Wallis testi sonuçları aşağıdaki tablolarda özetlenmiştir.

Tablo 5. İş Doyum Düzeyi Açısından Öğretmenlik Mesleğine Değer Verme boyutuna ilişkin Anova Testi Sonuçları

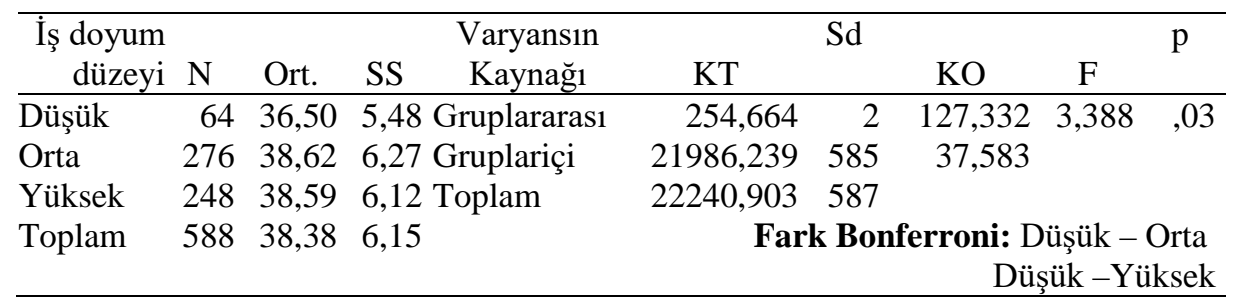

Yukarıdaki tablo incelendiğine öğretmenlerin iş doyum düzeyi açısından öğretmenlik mesleğine değer verme alt boyutunda puan ortalamaları arasındaki fark Anova testine göre anlamlı çıkmıştır $(F=3,388 ; p<0,05)$. Anlamlı farkların hangi gruplar arasında olduğunu belirlemek için homojenlik testinin sonucuna göre (Levene $=0,419 ; p=0,658)$ Bonferroni testi uygulanmıştır. Buna göre, düşük iş doyumuna sahip öğretmenler orta ve yüksek düzeyde iş doyumuna sahip öğretmenlerden anlamlı düzeyde öğretmenlik mesleğine daha az değer verdikleri görülmüştür $\left(\mathrm{Ort}_{\text {düşük }}=36,50\right.$; $\mathrm{Ort}_{\text {orta }}=38,62$; Ort $\left._{\text {yüksek }}=38,59\right)$. Düşük iş doyumuna sahip olan öğretmenlerin, yaşamdan mutlu olmama, yaptıkları işe değer vermeme, iş stresi, yıpranmışlık ya da ücretin yaptıkları işe karşılık gelmediğini düşündükleri gibi nedenlerle öğretmenlik mesleğine değer verme konusunda diğer öğretmenlere kıyasla daha zayıf kalmalarına yol açtığı şeklinde yorumlanabilir. 
Tablo 6. İş Doyum Düzeyi Açısından Kruskal Wallis H Testi Sonuçları

\begin{tabular}{|c|c|c|c|c|c|c|c|}
\hline & $\begin{array}{l}\text { İş doyum } \\
\text { düzeyi }\end{array}$ & $\mathrm{N}$ & Sira Ort. & $\begin{array}{l}\text { Kruskal- } \\
\text { Wallis H }\end{array}$ & Sd & $\mathrm{p}$ & Mann Whitney U \\
\hline \multirow[t]{3}{*}{ Öğrenmenin Doğas1 } & Düşük & 64 & 227,52 & 17,159 & 2 & ,000 & Düşük-Orta \\
\hline & Orta & 276 & 319,84 & & & & Düşük-Yüksek \\
\hline & Yüksek & 248 & 283,58 & & & & Orta-Yüksek \\
\hline \multirow[t]{3}{*}{ Öğrenmeden Beklentiler } & Düşük & 64 & 212,75 & 17,626 & 2 & 000 & Düşük-Orta \\
\hline & Orta & 276 & 311,38 & & & & Düşük-Yüksek \\
\hline & Yüksek & 248 & 296,81 & & & & \\
\hline \multirow[t]{3}{*}{ Öğrenmeye İlişkin Kayg1 } & Düşük & 64 & 309,85 & 15,707 & 2 & 000 & Düşük-Yüksek \\
\hline & Orta & 276 & 319,95 & & & & Orta-Yüksek \\
\hline & Yüksek & 248 & 262,21 & & & & \\
\hline \multirow{3}{*}{ Öğrenmeye Açıklık } & Düşük & 64 & 212,72 & 16,683 & 2 & 000 & Düşük-Orta \\
\hline & Orta & 276 & 305,38 & & & & Düşük-Yüksek \\
\hline & Yüksek & 248 & 303,49 & & & & \\
\hline \multirow{3}{*}{$\begin{array}{l}\text { Öğretmenlik mesleğine } \\
\text { ilgisizlik }\end{array}$} & Düşük & 64 & 261,59 & 6,070 & 2 & 048 & Düşük-Yüksek \\
\hline & Orta & 276 & 285,68 & & & & \\
\hline & Yüksek & 248 & 312,81 & & & & \\
\hline \multirow[t]{4}{*}{ Mesleki Gelişime Açıklık } & Düşük & 64 & 377,13 & 17,861 & 2 & ,000 & Düşük-Orta \\
\hline & Orta & 276 & 290,41 & & & & Düşük-Yüksek \\
\hline & Yüksek & 248 & 277,73 & & & & \\
\hline & Toplam & 588 & & & & & \\
\hline
\end{tabular}

Öğretmenlerin iş doyum düzeyleri açısından normal dağılım görülmeyen alt boyutlarda uygulanan Kruskall Wallis $\mathrm{H}$ testinin sonuçlarına göre ise öğrenmenin doğası, öğrenmeden beklentileri, öğrenmeye ilişkin kaygı, öğrenmeye açıklık, öğretmenlik mesleğine ilgisizlik ve mesleki gelişime açıklık alt boyutlarında öğretmenlerin sıra ortalamaları arasındaki farkların anlamlı olduğu görülmüştür $\left(\mathrm{H}_{\text {doğas }}=17,159 ; \mathrm{p}<0,05 ; \mathrm{H}_{\text {beklentiler }}=17,626 ; \mathrm{p}<0,05 ; \mathrm{H}_{\text {kaygı }}=15,707 ; \mathrm{p}<0,05\right.$; $\mathrm{H}_{\text {açıklk }}=16,683 ; \mathrm{p}<0,05 ; \mathrm{H}_{\text {ilgisizlik }}=6,07 ; \mathrm{p}<0,05 ; \mathrm{H}_{\text {Mesleki gelişime açılklk }}=17,861 ;$ $\mathrm{p}<0,05)$. Söz konusu bu farkların hangi gruplar arasında olduğunu belirlemek için ikili karşılaştırmalar yapılmış ve aşağıdaki bulgulara erişilmiştir:

- Öğrenmenin doğasında orta düzeyde iş doyumuna sahip öğretmenler düşük ve yüksek düzeyde iş doyumuna sahip öğretmenlerden anlamlı düzeyde daha yüksek puanlara sahip oldukları görülmüştür.

- Öğrenmeden beklentiler alt boyutunda ise düşük iş doyuma sahip öğretmenler yüksek ve orta düzeyde iş doyumuna sahip öğretmenlerden anlamlı düzeyde daha düşük beklenti içerisinde oldukları görülmüştür. 
- Öğrenmeye ilişkin kaygılarda ise yüksek iş doyumuna sahip öğretmenler düşük ve orta düzeyde iş doyumuna sahip öğretmenlerden anlamlı düzeyde daha düşük puanlara sahip oldukları görülmüştür.

- Öğrenmeye açıklık alt boyutunda ise düşük iş doyuma sahip öğretmenler yüksek ve orta düzeyde iş doyumuna sahip öğretmenlerden anlamlı düzeyde daha düşük puanlara sahip oldukları görülmüştür.

- Öğretmenlik mesleğine ilgisizlik alt boyutunda ise yüksek iş doyumuna sahip öğretmenlerin düşük iş doyumuna sahip öğretmenlere kıyasla daha yüksek bir puana sahip oldukları görülmüştür.

- Öğretmenlikte mesleki gelişime açıklık alt boyutunda düşük iş doyumuna sahip öğretmenler orta ve yüksek iş doyumuna sahip öğretmenlerden anlamlı düzeyde daha yüksek puan ortalamasına sahip oldukları görülmektedir.

\section{Öğrenmeye İlişkin Tutumlar ile Öğretmenlik Mesleğine İlişkin Tutumlar Arasındaki İlişkiye Yönelik Bulgular ve Yorum}

Ortaöğretim öğretmenlerinin öğrenmeye ilişkin tutumları ile öğretmenlik mesleğine ilişkin tutumları arasında anlamlı bir ilişkinin olup olmadığını belirlemek için yapılan Pearson Momentler çarpımı korelasyonun testinin sonuçları aşağıdaki tabloda özetlenmiştir. Tabloda görüldüğü gibi;

Öğretmenlerin öğrenmenin doğasına ilişkin tutumları ile

- Öğrenmeden beklentiler alt boyutu arasında orta düzeyde pozitif yönlü $(\mathrm{r}=0,67 *)$

- Öğrenmeye ilişkin kaygı alt boyutu arasında çok zayıf düzeyde negatif yönlü $\left(\mathrm{r}=-0,25^{*}\right)$

- Öğrenmeye açıklık alt boyutu arasında orta düzeyde pozitif yönlü (r= $\left.0,61^{*}\right)$

- Öğretmenlik mesleğine değer verme alt boyutu arasında düşük düzeyde pozitif yönlü $\left(\mathrm{r}=0,21^{*}\right)$

- Mesleki tükenmişlik alt boyutu arasında düşük düzeyde pozitif yönlü $\left(\mathrm{r}=0,12^{*}\right)$

- Mesleki ilgisizlik alt boyutu arasında düşük düzeyde pozitif yönlü (r= $0,18)$

- Öğretmenlik mesleki gelişime açıklık alt boyutu arasında orta düzeyde negatif yönlü $\left(\mathrm{r}=-0,33^{*}\right)$ ilişkileri söz konusu olduğu sonucuna varılmıştır. 
Tablo 7. Öğretmenlik Mesleğine İlişkin Tutumlar ile Öğrenmeye İlişkin Tutumlar Arasındaki Pearson Momentler Çarpımı Korelasyon testi Sonuçları

\begin{tabular}{|c|c|c|c|c|c|c|c|}
\hline & $\begin{array}{l}\text { Öğrenmeden } \\
\text { Beklentiler }\end{array}$ & $\begin{array}{l}\text { Ö ğrenmeye } \\
\text { İlişkin } \\
\text { Kayg1 }\end{array}$ & $\begin{array}{l}\text { Öğrenmeye } \\
\text { Açıklık }\end{array}$ & $\begin{array}{l}\text { Değer } \\
\text { Verme }\end{array}$ & $\begin{array}{l}\text { Mesleki } \\
\text { Tükenmişlik }\end{array}$ & İlgisizlik & $\begin{array}{l}\text { Mesleki } \\
\text { Gelişime } \\
\text { Açıklık }\end{array}$ \\
\hline Öğrenmenin & r ,670* &,$- 250^{*}$ & ,609* & $216^{*}$ & $117^{*}$ & $184^{*}$ &,$- 330^{*}$ \\
\hline Doğas1 & $\mathrm{p}, 000$ &, 000 &, 000 & 000 &, 004 & 000 &, 000 \\
\hline Öğrenmeden & r 1 &,$- 387^{*}$ &, $741^{*}$ & $216^{*}$ & $131^{*}$ & $160^{*}$ &,$- 434^{*}$ \\
\hline Beklentiler & $\mathrm{p}$ &, 000 & ,000 &, 000 & ,001 &, 000 & ,000 \\
\hline Öğrenmeye İlişkin & $\mathrm{r}$ & 1 &,$- 485^{*}$ &,$- 104^{*}$ & ,028 &,$- 163^{*}$ &, $335^{*}$ \\
\hline Kayg1 & $\mathrm{p}$ & & ,000 & ,012 & ,503 & ,000 & ,000 \\
\hline Öğrenmeye & $\mathrm{r}$ & & 1 & $247^{*}$ & ,038 & $153^{*}$ &,$- 432^{*}$ \\
\hline Açıklık & $\mathrm{p}$ & & & ,000 & ,355 & ,000 &, 000 \\
\hline \multirow[t]{2}{*}{ Değer Verme } & $\mathrm{r}$ & & & 1 &,- 016 &, $505^{*}$ &,$- 191^{*}$ \\
\hline & $\mathrm{p}$ & & & & ,693 & ,000 &, 000 \\
\hline Mesleki & $r$ & & & & 1 &,- 070 &, $213^{*}$ \\
\hline Tükenmişlik & $\mathrm{p}$ & & & & & 089 &, 000 \\
\hline \multirow[t]{2}{*}{ Mesleğe İlgisizlik } & $\mathrm{r}$ & & & & & 1 &,$- 220^{*}$ \\
\hline & $\mathrm{p}$ & & & & & & ,000 \\
\hline
\end{tabular}

$\mathrm{r}=$ Pearson korelasyon katsayıs1; $\mathrm{n}=588,{ }^{*}=\mathrm{p}<0,05$.

$\mathrm{Bu}$ bulgulardan yola çıkarak ortaöğretim öğretmenlerinin öğrenmenin doğasına ilişkin tutumları olumlu oldukça öğrenmeden beklentilerin, öğrenmeye açık olma durumları, öğretmenlik mesleğine değer verme, mesleki tükenmişlikleri ve mesleki ilgisizlik tutumlarının artması beklenmektedir. Öğrenmeye ilişkin kaygıları ve mesleki gelişime açı olma durumlarında ise bir düşüşün beklenmesi söz konusudur. Bir başka ifade ile lise öğretmenlerinin öğrenmenin doğasına ilişkin olumlu tutumlara sahip oldukça öğrenmeden beklentileri, öğrenmeye açık olma, mesleğe değer verme, mesleki tükenmişlikleri ve mesleki ilgisizliklerinin artması söz konusu iken öğrenmeye ilişkin kaygılarının azalması ile birlikte mesleki gelişime kapandıkları şeklinde yorumlanabilir.

Öğretmenlerin öğrenmeden beklentilere ilişkin tutumları ile

- Öğrenmeye ilişkin kaygı alt boyutu arasında orta düzeyde negatif yönlü $\left(\mathrm{r}=-0,38^{*}\right)$

- Öğrenmeye açılklı alt boyutu arasında yüksek düzeyde pozitif yönlü (r= $0,74 *)$

- Öğretmenlik mesleğine değer verme alt boyutu arasında düşük düzeyde pozitif yönlü $\left(\mathrm{r}=0,21^{*}\right)$

- Mesleki tükenmişlik alt boyutu arasında düşük düzeyde pozitif yönlü (r= $\left.0,13^{*}\right)$ 
- Mesleki ilgisizlik alt boyutu arasında düşük düzeyde pozitif yönlü (r= $\left.0,16^{*}\right)$

- Öğretmenlik mesleki gelişime açıklık alt boyutu arasında orta düzeyde negatif yönlü $\left(\mathrm{r}=-0,434^{*}\right)$ ilişkileri söz konusu olduğu sonucuna varılmıştır.

$\mathrm{Bu}$ bulgulardan hareketle öğretmenlerin öğrenmeden beklentileri arttıkça öğrenmeye açık olma, öğretmenlik mesleğine değer verme, mesleki tükenmişlik ve mesleğe ilgisizliklerinin artması beklenir. Oysaki öğrenmeye ilişkin kaygıları ve mesleki gelişime açık olmaya ilişkin tutumlarının ise azalması beklenir. Bir başka ifade ile lise öğretmenlerinin öğrenmeden beklentileri arttıkça öğrenmeye daha açık oldukları, öğretmenlik mesleğine daha fazla değer verdikleri, mesleki tükenmişlik duygusuna daha fazla kapıldıkları ve mesleğe ilgisizliklerinin arttı̆̆ 1 görülmektedir. Ayrıca öğrenmeye ilişkin kaygıları azalmakta ve mesleki gelişime kapandıkları şeklinde yorumlanabilir.

Öğretmenlerin öğrenmeye ilişkin kaygıları ile

- Öğrenmeye açıklık alt boyutu arasında orta düzeyde negatif yönlü (r= $\left.0,485^{*}\right)$

- Öğretmenlik mesleğine değer verme alt boyutu arasında düşük düzeyde negatif yönlü $(\mathrm{r}=-0,104 *)$

- Mesleki ilgisizlik alt boyutu arasında düşük düzeyde negatif yönlü (r= $\left.0,163^{*}\right)$

- Öğretmenlik mesleki gelişime açıklık alt boyutu arasında orta düzeyde pozitif yönlü $\left(r=0,335^{*}\right)$ ilişkileri söz konusu olduğu bulgusuna varılmıştır.

Yukarıdaki bulgulara göre öğretmenlerin öğrenmeye ilişkin kaygıları arttıkça mesleki gelişime ilişkin tutumları artarken, öğrenmeye açık olma, mesleğe değer verme ve mesleğe ilgisizliklerinin azaldığ şeklinde yorumlanabilir. Bir başka ifade ile öğretmenlerin öğrenmeye ilişkin kaygıları arttıkça öğrenmeye açıklıkları, mesleğe değer vermeleri ve mesleğe ilgisizliklerinin azalması beklenirken, mesleki gelişime daha açık olmaları yönünde de bir beklenti söz konusu olmaktadır.

Öğretmenlerin öğrenmeye açık olma tutumları ile

- Öğretmenlik mesleğine değer verme alt boyutu arasında düşük düzeyde pozitif yönlü $\left(\mathrm{r}=0,247^{*}\right)$

- Mesleki ilgisizlik alt boyutu arasında düşük düzeyde pozitif yönlü (r= $\left.0,153^{*}\right)$

- Öğretmenlik mesleki gelişime açıklık alt boyutu arasında orta düzeyde negatif yönlü $(\mathrm{r}=-0,432 *)$ ilişkileri söz konusu olduğu sonucuna varılmıştır.

Söz konusu bu bulgulara göre öğretmenlerin öğrenme açık olma tutumları arttıkça mesleğe değer vermeleri ve mesleğe ilgisiz davranmaları beklenir ve mesleki gelişime açık olma tutumlarının ise azalması beklenir. 
Öğretmenlerin öğretmenlik mesleğine değer verme tutumları ile

- Mesleki ilgisizlik alt boyutu arasında orta düzeyde pozitif yönlü $\left(\mathrm{r}=0,505^{*}\right)$

- Öğretmenlik mesleki gelişime açıklık alt boyutu arasında düşük düzeyde negatif yönlü $\left(\mathrm{r}=-0,191^{*}\right)$ ilişkileri söz konusu olduğu sonucuna varılmıştır.

Ortaöğretim öğretmenlerinin öğretmenlik mesleğine değer verdikçe mesleki ilgisizlikleri artarken mesleki gelişime açı olma durumlarının azaldığı sonucuna varılmıştır.

Öğretmenlerin öğretmenlik mesleğine ilişkin tükenmişlik tutumları ile öğretmenlik mesleğinde gelişime açıklık alt boyutu arasında düşük düzeyde pozitif yönlü $\left(r=0,213^{*}\right)$ ilişkileri söz konusu olduğu sonucuna varılmıştır. Buna göre mesleki tükenmişlik arttıkça mesleki gelişime açık olma durumlarının da artığ1 söylenebilir.

Öğretmenlerin öğretmenlik mesleğine ilgisizlikleri ile mesleki gelişime açık olma tutumları arasında düşük düzeyde negatif yönlü $(r=-0,220 ; p>0,05)$ ilişkileri söz konusu olduğu sonucuna varılmıştır. Düşük düzeyde de olsa öğretmenlerin mesleğe ilgisizlikleri arttıkça mesleki gelişime daha kapalı olma eğilimde oldukları şeklinde yorumlanabilir.

\section{SONUÇ, TARTIŞMA ve ÖNERILER}

\section{Öğretmenlerin Tutumlarında Kıdemleri Açısından Sonuçlar}

Öğretmenlerin kıdemleri açısından öğretmenlik mesleğe ilgisizlik boyutunda 21 y1l ve üstü k1deme sahip öğretmenlerin, 6-15 yıl arasında kıdeme sahip öğretmenlere göre anlamlı düzeyde daha yüksek mesleki ilgisizliğe sahip oldukları sonucuna varılmıştır. Ancak Kuyumcu (2019)'nun Kars ili ve köylerinde görev yapan 128 öğretmen ile yaptı̆̆ araştırmada 0-5 yıl kıdeme sahip öğretmenlerin mesleki tükenmişlik ve ilgisizlik boyutu algılarının 11-15 yıl kıdeme sahip öğretmenlerin algılarından daha yüksek çıktığı görülmektedir. Kuyumcu'nun sonuçları ile bu araştırmanın öğretmenlerin kıdemleri açısından örtüşmemesi incelenen örneklemin bölge farklılı̆̆ından kaynaklandığ 1 düşünülmektedir. Genel anlamda öğretmenlerin motivasyon yetersizliği ve mesleki tükenmişlik yaşamaları mesleğe olan ilgisizliği artırdığ düşünülmektedir.

Öğrenmeden beklentilere ve öğrenmeye açıklığa ilişkin tutumlarda ise 1-5 yıl ile 6-10 yıl arasında kıdeme sahip olan öğretmenlerin, 11 yıl ve üstü kıdeme sahip olan öğretmenlerden anlamlı düzeyde daha fazla öğrenmeden beklenti içerisinde oldukları ve öğrenmeye daha açık oldukları görülmüş̧ür. Bu sonuç, meslekteki kıdemin artması beraberinde öğrenme isteksizliğini de artırdığını göstermektedir. 
Yaman ve Yazar (2014)'ın yaptıkları araştırma sonuçları da kıdemleri 6- 10 yıl arasında olan öğretmenlerin daha yüksek kıdeme sahip olan öğretmenlere oranla yaşam boyu öğrenmeye daha çok olumlu tutum sahibidirler. Yaşam boyu öğrenmeyi bir anlamda sürekli öğrenme isteğinin devam etmesi olarak kabul edebileceğimize göre, bu sonucun, yapılan bu araştırmanın sonucuyla örtüştüğünü ifade edebiliriz. Ayrıca, Murathan (2014)'ın ve İpek (2015)'in yaptıkları çalışmalarda da elde edilen bulguların bu çalışmamızda elde edilen sonucu desteklediği görülmektedir. Bu sonuç, öğretmenlik mesleğine yeni başlamanın ve mesleki bilgiye daha çok ihtiyaç hissetmenin öğretmenlerde azim ve motivasyon sağlamış olmasının etkili olabileceğini düşündürmektedir. Kıdem artsa da öğretmenlik mesleğinde gelişmelerin sürekli takip edilmesi bir anlamda mesleki sorumluluk olduğundan öğretmenlerin öğrenmeye daha açık olmaları gerekmektedir.

Araştırmanın elde edilen bir başka sonucuna göre öğretmenlik kariyerinin ortalarına kadar öğretmenlik mesleğine değer verme azalırken mesleki gelişime açıklı artmakta ve kariyerine sonuna doğru değer verme artarken mesleki gelişime açıklık azalmaktadır. $\mathrm{Bu}$ verilere dayanarak, öğretmenlerin kariyerlerinin sonuna doğru değer verme tutumlarının artması sahip olunan statünün kaybedilmesi endiş̧esinden kaynaklandığı düşünülmektedir. Mesleki gelişime açıklık tutumlarının ilk yıllarda yüksek olması, meslekte yeni olmanın verdiği heyecan, sahiplenme ve genel anlamda üst sosyal statüye erişmiş olma ayrıcalığından kaynaklanmakta iken mesleğin sonuna doğru ise bu ayrıcalığın kaybediliyor olmasının verdiği endişeden kaynaklanabileceği düşünülmektedir.

\section{Öğretmenlerin Tutumlarında Eğitim Düzeyleri Açısından Sonuçlar}

Lisans ve yüksek lisans düzeyinde mezun olan öğretmenlere kıyasla doktora mezunu ortaöğretim öğretmenlerinin mesleki gelişime daha açı oldukları, öğrenmenin doğasına ve öğrenmeden beklentilere ilişkin tutumlarının daha olumlu olduğu görülmüştür. Bu durum, eğitim düzeyinin yükselmesinin beraberinde öğretmenlere kazandırdığı hızlı adaptasyon sağlama özelliği sayesinde, eğitim, öğrenme ve öğretim alanındaki değişmelere ve hızla devam eden yeniliklere kolay uyum sağlayabilmeleri olarak açıklanabilir. Öğretmenlik mesleğinde duyuşsal özellik önemli olduğu kadar, bilgi sahibi olma özellikle bilginin hızla arttığı ve aynı hızla değiştiği günümüz dünyasında öğrenmeye sürekli açık olma özelliği çok daha önemli olmuştur. Hayat boyu öğrenmenin bir yolu da sürekli öğrenci olmaktan geçmektedir. Bu durumda eğitim düzeyinin devam ediyor olmasının, öğrenen birey modelinin de sürdürülmesi olduğu kabul edilebilir.

\section{Öğretmenlerin Tutumlarında İş Doyum Düzeyleri Açısından Sonuçlar}


İş doyum düzeyleri açısından, öğrenmeye ve öğretmenlik mesleğine ilişkin tutum puanları arasındaki farkın anlamlı olduğu görülmüştür.

Orta ve yüksek düzeyde iş doyumuna sahip öğretmenler düşük iş doyumuna sahip öğretmenlere kıyasla öğrenmenin doğasına ilişkin tutumları, öğrenmeden beklentileri ve öğrenmeye açık olma tutumlarının daha yüksek olduğu sonucuna varılmıştır.

Düşük iş doyumuna sahip olan öğretmenlerin diğer öğretmenlere kıyasla öğretmenlik mesleğine daha fazla değer verdikleri ve mesleki gelişime daha açık oldukları sonucuna varılmıştır.

İş doyumu yüksek öğretmenler diğer öğretmenlere kıyasla öğrenmeye ilişkin kaygılarının daha az olduğu ve öğretmenlik mesleğine de daha az ilgi gösterdikleri görülmüştür.

\section{Öğrenmeye İlişskin Tutumlar ile Öğretmenlik Mesleğine İlişkin Tutumlar Arasındaki İlişkiye Yönelik Sonuçlar}

Ortaöğretim öğretmenlerinin öğrenmeye ilişkin tutumlarının alt boyutları ile öğretmenlik mesleğine ilişkin alt boyutları arasındaki ilişki incelendiğinde:

- Öğrenmenin doğasına ilişkin tutum arttıç̧a öğrenmeye ilişkin beklentiler, öğrenmeye açık olma, öğretmenlik mesleğine değer verme, mesleki tükenmişlik ve mesleki ilgisizliğin arttığ 1 ;

- Öğretmenlerin Öğrenmeye ilişkin beklentileri arttıkça öğrenmeye açık olma durumları, mesleğe değer verme, mesleki tükenmişlikleri ve mesleki ilgisizliklerinin de arttı $\breve{g}$;

- Öğretmenlerin öğrenmeye açık olmaya ilişkin tutumu arttıkça mesleğe değer verme, mesleki tükenmişlikleri ve mesleki ilgisizlikleri de arttı̆̆ı;

- Öğretmenlerin öğretmenlik mesleğine değer verme tutumu arttıkça mesleki ilgisizliklerinin de arttığı görülmektedir.

Diğer taraftan ortaöğretim öğretmenlerinin öğrenmenin doğasına ilişkin tutumu, öğrenmeden beklentileri, öğrenmeye açık olma durumları ve öğretmenlik mesleğine değer verme tutumu arttıkça öğrenmeye ilişkin kaygıları ve mesleki gelişime açık olma durumlarının da azaldığı görülmektedir.

\section{Öneriler}

2019-2020 birinci yarıyılında Malatya Merkez ilçelerinde ortaöğretim öğretmenlerinin öğrenmeye ve öğretmenlik mesleğine ilişkin tutumlarının araştırıldığı bu çalışmada elde edilen sonuçlar doğrultusunda aşağıdaki önerilerde bulunulmuştur: 
- Eğitimde hedeflenen öğrenme ve öğretme niteliğinin artırılması için öğretmenlerin öğretmenlik mesleğine ve öğrenmeye ilişkin tutumlarının olumlu şekilde artırılmasına yönelik bir devlet politikasının geliştirilmesi gerekmektedir. Korelasyon sonuçları dikkate alındığında alt boyutlarda oluşacak olumlu bir gelişmenin diğer alt boyutları da olumlu şekilde etkileyecektir. Bu açıdan bakıldığında, öğretmenlik mesleğinin kanununun çıkarılması mesleğin önemini ve statüsünü olumlu etkileyeceği, öğretmenlerin tutumlarının da kaçınılmaz bir şekilde olumlu yönde artıracağı umulmaktadır.

- Öğretmenlerin öğrenmeye ve öğretmenlik mesleğine ilişkin tutumlarının daha da iyileştirilmesi amacıyla, her eğitim-öğretim yılının başında ya da sonunda yapılan seminer dönemi çalışmaları ile öğretmenlerin öğrenmeye ve öğretmenlik mesleğine ilişkin görüşleri alınmalı ve değerlendirilmelidir. Buna yönelik olarak yıl boyunca devam edecek konu alanı uzmanları ile eylem planları düzenlenmelidir.

- Çağımızda bilimsel ve teknolojik gelişmelerle birlikte sosyolojik ve psikolojik anlamda değişen insan ilişkilerinde oldukça önemli bir etken haline gelen, öğrenme ve öğretmenlik mesleği hakkında bilgilendirici çalışmaların belli aralıklarla tüm öğretmenlere hizmet içi eğitim yoluyla verilmesinin yararlı olacağ düşünülmektedir.

- Lisan, yüksek lisans ve doktora mezunu öğretmenlerin tutumları dikkate alındığında öğretmenlerin akademik çalışmalara yönlendirilmelerinin olumlu yönde tutum geliştirmelerini sağladığg 1 görülmüştür. Bu nedenle her ilde bulunan üniversitelerin belirli bir kontenjanını meslekteki öğretmenlerin akademik çalışmalarına ayırmasının eğitim niteliğini artıracağı düşünülmektedir. $\mathrm{Bu}$ anlamda MEB'in başlatmış olduğu akademik çalışma yapan öğretmenlere yönelik ek hizmet puanının verilmesinin olumlu etki yaptığ ancak bunun verilmekte olan artırımlı ek ders ücreti hususunda da daha fazla artırılarak desteklenmesi durumunda daha da teşvik edici olabileceği önerilir.

\section{KAYNAKÇA}

Aktürk, A. O. (2012). Öğretmen adaylarının öğrenmeye ilişkin tutumlarının öğretmenlik mesleğini tercih etme nedenlerine ve akademik başarılarına göre incelenmesi. Ahi Evran Üniversitesi Kırşehir Ë̆itim Fakültesi Dergisi (KEFAD),13(3), 283-297.

Arı, E. (2011). Temel kavramlar. ögrrenme ögrretme kuram ve yaklaşımları. (1 Baskı). Sevil Büyükalan Filiz (Editör). Pegem Akademi Yayıncılık.

Arkonaç, S. (1998). Psikoloji zihin süreçleri bilimi. Alfa Basın Dağıtım. 
Baykara Pehlivan, K. (2008). Sınıf öğretmeni adaylarının sosyo - kültürel özellikleri ve öğretmenlik mesleğine yönelik tutumları üzerine bir çalışma. Mersin Üniversitesi Eğitim Fakültesi Dergisi, 4(2), 151-168.

Bilgin, H. (1996). Okul öncesi ĕgitim kurumlarında çalışan öğretmenlerin ögretmenlik tutumlarının incelenmesi. [Yayımlanmamış Yüksek Lisans] Tezi, Marmara Üniversitesi.

Bozdoğan, A.E., Aydın, D. ve Yıldırım, K. (2007). Öğretmen adaylarının öğretmenlik mesleğine ilişkin tutumları. Ahi Evran Üniversitesi Kırşehir Ĕ̈itim Fakültesi Dergisi, 8(1), 209-222.

Bursalığlu, Z. (1994). Okul yönetiminde yeni yapı ve davranış. Pegem Yayın.

Büyüköztürk, Ş. (2014). Sosyal bilimler için veri analizi el kitabı. 20. Bask1. Pegem Akademi.

Can, G. (1987). Öğretmenlik meslek anlayışı üzerine bir araştırma. Anadolu Üniversitesi Eğitim Fakültesi Dergisi, 2(1).

Canakay, E. U. (2006). Müzik teorisi dersine ilişkin tutum ölçeği geliştirme. Ulusal Müzik Eğitimi Sempozyumu Bildirisi. Pamukkale Üniversitesi Eğitim Fakültesi, Denizli 26-28 Nisan.

Chan, K. W. and Elliott, R. G. (2004). Relational analysis of personal epistemology and conceptions about teaching and learning. Teaching and Teacher Education, 20, 817-831.

Chan, K. W., Tan, J. and Khoo, A. (2007). Pre-Service teachers' conceptions about teaching and learning: A closer look at singapore cultural context. Asia-Pacific Journal of Teacher Education, 35(2), 181-195.

Çakır, Ö. (2005). Anadolu üniversitesi Açıköğretim Fakültesi İngilizce Öğretmenliği Lisans Programı ve Eğitim Fakülteleri İngilizce Öğretmenliği Lisans Programı Öğrencilerinin Mesleğe Yönelik Tutumları ve Mesleki Yeterlik Algıları. İnönü Üniversitesi Eğitim Fakültesi Dergisi, 6 (9), 27-42.

Çakmak, E.K., Akgün Ö.E., Karadeniz Ş., Büyüköztürk Ş. ve Demirel, F. (2008). İlköğretim ikinci kademe ve lise öğrencilerinin ders ve sınıf düzeylerine göre öğrenme stratejileri ve güdülenme düzeylerinin belirlenmesi. Uluslararasi İnsan Bilimleri Dergisi, 5(1), 1-27.

Çapa Y. ve Çil, N. (2000). Öğretmen adaylarının öğretmenlik mesleğine yönelik tutumlarının farklı değişkenler açısından incelenmesi. Hacettepe 
Üniversitesi Eğitim Fakültesi Dergisi, 18, 67-73.

Çapri, B. ve Çelikkaleli, Ö. (2008). Öğretmen adaylarının öğretmenliğe ilişkin tutum ve mesleki yeterlik inançlarının cinsiyet, program ve fakültelerine göre incelenmesi. İnönü Üniversitesi Ĕgitim Fakültesi Dergisi, 15(9), 3353.

Çetin, Ş. (2003). Anadolu Öğretmen Lisesi ve Düz Lise çılışlı eğitim fakültesi ögrrencilerinin ögrretmenlik mesleğine yönelik tutumlarının karşılaştırılması. Yayımlanmamış doktora tezi, Gazi Üniversitesi.

Çelik, S., Yıldırım, D., Batur, Ö., Çime, E., Çapraz, F. ve Kubat, N. (2014). Öğrenci hemşirelerin öğrenme stratejileri ve stillerinin belirlenmesi. Ankara Sağllk Hizmetleri Dergisi, 13(1), 13-27.

Çelikten, M., Şanal, M. ve Yeni, Y. (2005). Öğretmenlik mesleği ve özellikleri. Erciyes Üniversitesi Sosyal Bilimler Enstitüsü Dergisi, 19(2), 207-237.

Dağ, E. (2010). Sinıf ögretmen adaylarının ögrretmenlik mesleğine yönelik tutumlar ile ögretmenlik mesleğini tercih etmelerinde etkili olan faktörler arasındaki ilişki (İzmir örneği). Yayımlanmamış yüksek lisans tezi, Ege Üniversitesi Sosyal Bilimler Enstitüsü.

Duatepe, A. ve Akkuş-Çıkla, O. (2004). The attitudes towards teaching professions of inservice and preservice primary school teachers. Pedagogy Studies (Pedagogika), 70, 61-65.

Demirel, Ö. (2012). Öğretim ilke ve yöntemleri ögretme sanatı. (19. Bask1). Pegem Akademi Yayınc1lik.

Demirel, N. ve Ünişen, A. (2018). Öğretmenlerin öğretmenlik mesleğine ilişkin tutum ölçeğinin geliştirilmesi. Elektronik Sosyal Bilimler Dergisi, 17(67), 997-1013.

Demirtaş, H. ve Özer, N. (2011). Öğretmen adaylarının öz-yeterlik algıları ile öğretmenlik mesleğine yönelik tutumları. Eğitim ve Bilim Dergisi, 36(159), 96-11.

Duman, B. (2008). Öğrenme ögrretme kuramlart ve süreç temelli öğrenme. (2. Bask1). An1 Yayınc1l1k.

Erkuş, A., Sanlı, N., Bağlı, M. T. ve Güven, K. (2000). Öğretmenliğe ilişkin tutum ölçeği geliştirilmesi. Ĕgitim ve Bilim, 25(116).

Ertürk, E. ve Keçecioğlu, T. (2012). Çalışanların iş doyumları ile mesleki 
tükenmişlik düzeyleri arasındaki ilişkiler: öğretmenler üzerine örnek bir uygulama. Ege Akademik Bakış, 12(1), 41-54.

Fındıkçı, İ. (1991). Öğretmenlerin disiplin konusundaki tutumları. eğitimde nitelik geliştirme, Eğitimde Arayışlar 1. Sempozyumu Bildiri Metinleri. Kültür Yayınları.

Garfield, J.C. (1973). Effects of The child's social classes on school counsellor's decision making. Journal of Counselling Psychology, 20.

Gündoğan, N. (2003). Avrupa Birliği’ne üye ülkelerde bir istihdam politikas1 aracı olarak yaşam boyu öğrenme ve bazı örnek program ve uygulamalar. Кamu-Işş̧ Hukuku ve İktisat Dergisi,7(2).

Güdek, B. (2007). Eğitim Fakültesi Müzik Eğitimi Anabilim Dalı 1. ve 4. Sinıf ögrencilerinin müzik ögrretmenliği mesleğine yönelik tutumlarının ögrenciye ait farklı değişkenler açısından incelenmesi. [Yayınlanmamış Doktora Tezi], Gazi Üniversitesi Eğitim Bilimleri Enstitüsü.

Gürbüz, H. ve Kışoğlu, M. (2007). Tezsiz yüksek lisans programına devam eden fen-edebiyat ve eğitim fakültesi öğrencilerinin öğretmenlik mesleğine yönelik tutumları (Atatürk Üniversitesi örneği). Erzincan Eğitim Fakültesi Dergisi, 9(2), 71-83.

Gürbüztürk, O. ve Genç, S. Z. (2004). Öğretmen adaylarının öğretmenlik mesleğine ilişkin görüşleri. İnönü Üniversitesi Eğitim Fakültesi Dergisi, 5(7), 47-62.

Gürkan, T. (1993). İlkokul öğretmenlerinin öğretmenlik tutumlartyla benlik kavramları arasındaki ilişsi. Sevinç Matbaası.

Güven, M. ve Kürüm, D. (2006). Öğrenme stilleri ve eleştirel düşünme arasındaki ilişkiye genel bir bakış. Sosyal Bilimler Dergisi, 1, 75-90.

Hancock, E. S. and Gallard, A. J. (2004). Preservice science teachers' beliefs about teaching and learning: the influence of k-12 field experiences. Journal of Science Teacher Education, 15(4), 281-291.

İpek, S. (2015). Temel ĕgitimde görev yapan ögretmenlerin slnuf yönetimi özyeterlik inançlar ve mesleki tutumları (Rize İli Örneği). Avrasya Üniversitesi.

İzci, E. ve Kara, A. (2010). Fransa'da eğitim personelinin hizmet içi eğitimi. Adlyaman Üniversitesi Sosyal Bilimler Enstitüsü Dergisi, 3(5), 161-168. 
Kara, A. (2010). Öğrenmeye ilişkin tutum ölçeğinin geliştirilmesi. Elektronik Sosyal Bilimler Dergisi, 9(32), 49-62.

Kara, A., İzci, E. ve Ulutaş, A. (2011). Resmi ve özel ilköğretim birinci kademede öğrenim gören öğrencilerin öğrenmeye ilişkin tutumları. e-Journal of New World Sciences Academy, 6(1), 988-1006.

Kara, A., Tekin, H., Ünişen, A. ve İzci, E. (2016). Ortaokul öğrencilerinin öğrenmeye ilişkin tutumlarının incelenmesi. Ĕgitim ve Öğretim Araştırmaları Dergisi, 5(2), 56-65.

Karagözoğlu, G. (1987). Yükseköğretime geçişte öğretmenlik mesleğine yönelme. Hacettepe Üniversitesi Eğitim Fakültesi Dergisi, 6(2), 35-46.

Karasar, N. (2005). Bilimsel araştırma yöntemi: kavramlar, ilkeler ve teknikler. Nobel Yayıncilik.

Kaya, H. ve Akçin, E. (2002). Öğrenme biçimleri, stilleri ve hemşirelik eğitimi. Cumhuriyet Üniversitesi Hemşirelik Yüksekokulu Dergisi, 6(2), 31-35.

K1lıç, Ö.S. (2011). Illkögrretim okullarında görev yapan okul müdürü ve ögretmenlerin iş doyumu (Tokat İli Örneği). [Yüksek Lisans Tezi], Selçuk Üniversitesi.

Krull, E., Koni, I. and Oras, K. (2013). Impact on student teachers conception of learning and teaching from studying a course in educational psychology. Asia-Pacific Journal of Teacher Education, 41(2), 218-231

Kumaş, V. ve Deniz, L. (2010). Öğretmenlerin iş doyum Düzeylerinin İncelenmesi. M.Ü. Atatürk Eğitim Fakültesi Eğitim Bilimleri dergisi, 32, 123-139.

Kuyumcu, E. (2019). Öğretmenlerin mesleki genel yeterlik algıları ile ögretmenlik mesleklerine yönelik tutumlarının incelenmesi. [Yüksek Lisans Tezi], Kafkas Üniversitesi.

Küçükahmet, L. (1976). Öğretmen yetiştiren kurum ögretmenlerinin tutumlart. Ankara Üniversitesi Eğitim Fakültesi Yayınları.

Malsawmi H. and Renthlei, M. (2015). International journal of multidisciplinary. Approach \& Studies, 5/2(3), 121-127.

MEB (2019). 2023 Eğitim vizyonu. http://2023vizyonu.meb.gov.tr/, Erişim Tarihi: 10.09 .2020 
Murat, M., Ünişen, A. ve Kanadlı, S. (2010). Eğitim fakültesine yeni başlayan öğrencilerin öğretmenlik mesleğini algılayışları ve öğretmenlik mesleğine ilişkin tutumları. Elektronik Sosyal Bilimler Dergisi, 9(33), 226-244.

Murathan, T. (2014). Spor eğitimcilerinin bilgisayar destekli ĕgitim algılarının öğrenmeye ilişkin tutumları açısından değerlendirilmesi. Yayınlanmamış doktora tezi, Fırat Üniversitesi.

Oral, B. (1997). Öğretmen adaylarının öğretmenlik uygulamasına ilişkin görüşleri. Çă̆daş Eğitim Dergisi, 4, 223.

Osunde, A. U. and Izevbigie, T. I. (2006). An assessment of teachers' attitude towards teaching profession in Midwestern Nigeria. Education, 126(3), 462-467

Özden, Y. (2000). Öğrenme ve ögretme. Pegem Yayınevi.

Özdemir, H. (2015). Hemşirelik öğrencilerinin ögrrenme sitilleri ve psikomotor becerileri arasındaki ilişkinin incelenmesi. Yüksek Lisans Tezi, Ege Üniversitesi.

Özder, Y., Konedralı, G. ve Zeki, C.P. (2010). Öğretmen adaylarının öğretmenlik mesleğine yönelik tutumlarının çeşitli değişkenler açısından incelenmesi. Kuram ve Uygulamada Ë̆itim Yönetimi Dergisi, 16(2), 253-275.

Recepoğlu, E. (2013). Öğretmen adaylarının yaşam doyumları ile öğretmenlik mesleğine ilişkin tutumları arasındaki ilişkinin incelenmesi. Hacettepe Üniversitesi Ĕgitim Fakültesi Dergisi, 1, 311-326.

Rosnow, R. L. and Rosenthal, R. (1997). People studying people: Artifacts and ethics in behavioral research. W.H. Freeman

Rula L. D. (2006). University students’ beliefs about learning English and French in lebanon. System, 34(1), 80-96

Sağlam, A. Ç. (2008). Müzik öğretmenliği bölümü öğrencilerinin öğretmenlik mesleğine yönelik tutumları. Yüzüncü Yll Üniversitesi Ĕgitim Fakültesi Dergisi, 5, (1), 59-69

Sarıkaya, Ş. (2019). Öğretmenlerin iş doyumunun yordayıcısı olarak örgütsel güven ve örgütsel destek algisl. Yüksek Lisans Tezi, Marmara Üniversitesi, İstanbul Sabahattin Zam Üniversitesi.

Semerci, N. (2008). Anadolu öğretmen lisesi öğrencilerinin öğretmenliğe ilişkin 
tutumları. Firat Üniversitesi Sosyal Dergisi, 18(1), 139-157.

Schunk, H. D. (2009). Öğrenme teorileri ĕgitimsel bir bakış. Nobel Yayın.

Soran, H., Demirci, C. ve Atav, E. (1996). Hacettepe Üniversitesi Eğitim Fakültesi Fen Bilimleri öğrencilerinin öğretmenlik mesleğine yönelik tutumlarının belirlenmesi. II. Ulusal Fen Bilimleri Eğitimi Sempozyumu, Marmara Üniversitesi Atatürk Eğitim Fakültesi.

Sütçü, M. A. (1997). Din kültürü ve ahlak bilgisi ögrretmenlerinin ögrretmenlik tutumları. Yüksek lisans tezi, Gazi Üniversitesi.

Sözer, E. (1996). Üniversitelerde öğrenim gören öğretmen adaylarının öğretmenlik mesleğine yönelik tutumları. Anadolu Üniversitesi Eğitim Fakültesi Dergisi, 6(2), 7-21.

Şimşek, H. (2005). Ortaöğretim alan öğretmenliği tezsiz yüksek lisans programına devam eden öğrencilerin öğretmenlik mesleğine yönelik tutumları. Yüzüncü Yll Üniversitesi Eğitim Fakültesi Dergisi, 2(1), 25-50

Tanrıöğen, A. (1997). Buca eğitim fakültesi öğrencilerinin öğretmenlik mesleğine yönelik tutumları. Pamukkale Üniversitesi Ë̆itim Fakültesi Dergisi, (8)13, 17-22

Temizkan, M. (2008). Türkçe öğretmeni adaylarının öğretmenlik mesleğine yönelik tutumları üzerine bir araştırma. Türk Eğitim Bilimleri Dergisi, 6 (3), 461- 486.

Terzi, A.R. ve Tezci, E. (2007). Necatibey Eğitim Fakültesi öğrencilerinin öğretmenlik mesleğine ilişkin tutumları. Kuram ve Uygulamada Eğitim Yönetimi Dergisi, 13(4), 593-614.

Tigchelaar, A., Vermunt, J. D. and Brouwer, N. (2014). Patterns of development in second-career teachers' conceptions of teaching and learning. Teaching and Teacher Education, 41, 111-120.

Turgut, M. F. (1992). Eğitimde Ölçme ve Değerlendirme Metotları. Saydam Matbaacilik.

Ülgen, G. (1997). Eğitim Psikolojisi: Kavramlar, İlkeler, Yöntemler, Kuramlar ve Uygulamalar. 3. Baskı, Alkım Yayınları.

Wilson, J. H. (2008). Instructor Attitudes Toward Students: Job Satisfaction and Student Outcomes. College Teaching, 56(4), 225-229. 
Yalız, D. (2010). Anadolu Üniversitesi Beden Eğitimi ve Spor Öğretmenliği Bölümü öğrencilerinin öğretmenlik mesleğine yönelik tutumlarının karşılaştırılması. Celal Bayar Üniversitesi Beden Eğitimi ve Spor Bìlimleri Dergisi, 5(1), 7-14.

Yaman, F. ve Yazar, T. (2014). Öğretmenlerin yaşam boyu öğrenme eğilimlerinin incelenmesi (Diyarbakır ili örneği). K.Ü. Kastamonu Ĕ̈itim Dergisi, 23(4), 1553-1566.

Yazıcı, H. (2009). Öğretmenlik mesleği, motivasyon kaynakları ve temel tutumları: Kuramsal bir bakış. Kastamonu Eğitim Dergisi, 17(1), 33-46. 